VIII

\title{
ADDENDA ET CORRIGENDA
}

\author{
In vita Sophoclis
}

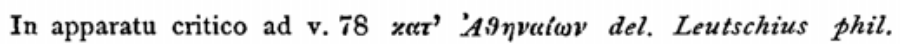
anz. VII p. 204 || 79 post «ँ $v \delta \rho$ idem excidisse putat quibus Sophoclem Bacchi delicias esse indicetur.

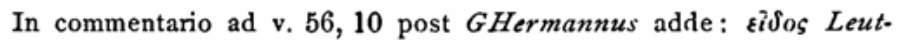
schius $l$. $l$.

\section{In Electra}

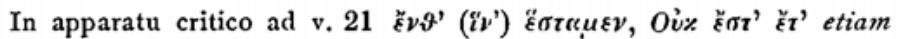

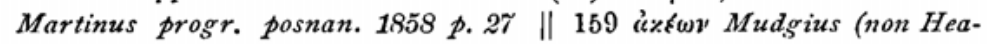
thius) || 174 Eั $\tau$ L Heathius || 515 GHMuellerus emend. et interpret. sophocl. p. 25 || $534 \pi \alpha \imath$ ị idem ibid. p. 26. 